\title{
EQUESTRIAN SYNOVIAL FLUID MESENCHYMAL STEM CELLS, A POTENTIAL EXPERIMENTAL MODEL FOR OSTEOARTICULAR THERAPIES
}

\author{
CRISTIAN MIHĂIȚĂ CRECAN ${ }^{1 *}$, SIMONA LUMINIȚA OPREAN ${ }^{2 *}$, MIRELA ALEXANDRA \\ TRIPON $^{3}$, ANDREI BODNARIUC ${ }^{4}$, LUCIANA RUS ${ }^{5}$, EMOKE PALL ${ }^{3 *}$, DANIELA CLAUDIA \\ OROS $^{6}$, IANCU MORAR ${ }^{3 \#}$
}

\author{
${ }^{1}$ University of Agricultural Sciences and Veterinary Medicine, Faculty of Veterinary Medicine, Department of Surgical \\ Techniques, 3-5 Mănăstur Street, 400372, Cluj-Napoca, Romania \\ 2 "Iuliu Hatieganu”, University of Medicine and Pharmacy, Faculty of Pharmacy, Department of General and Inorganic \\ Chemistry, Cluj-Napoca, Romania \\ ${ }^{3}$ University of Agricultural Sciences and Veterinary Medicine, Faculty of Veterinary Medicine, Department of Reproduction \\ and Obstetrics, 3-5 Mănăştur Street, 400372, Cluj-Napoca, Romania \\ ${ }^{4}$ University of Agricultural Sciences and Veterinary Medicine, Faculty of Veterinary Medicine, Department of Pathophysiology, \\ 3-5 Mănăştur Street, 400372, Cluj-Napoca, Romania \\ ${ }^{5}$ University of Agricultural Sciences and Veterinary Medicine, Faculty of Veterinary Medicine, Department of Parasitology, \\ 3-5 Mănăş̧ur Street, 400372, Cluj-Napoca, Romania \\ ${ }^{6}$ Private Practitioner, Cluj-Napoca, Romania
}

*corresponding author: lopreans@umfcluj.ro

${ }^{\#}$ Authors with equal contribution

Manuscript received: September 2018

\begin{abstract}
Mesenchymal stem cells (MSCs) therapy has become widely used to treat degenerative diseases. There are various tissue specific sources of stem cells with different therapeutic applications, therefore it is necessary to further investigate the characteristics and differences between MSCs from different origins, their potential and limitations. Osteoarthritis is the most common joint disease affecting both human and horses, and current treatment options have strong limitations. The use of MSCs to treat degenerative osteo-articular diseases has proven to be effective but further studies are needed to establish the safest and most effective protocol with regard to source, allogenic versus autologous cells and dose. Horses can be used as a large animal model for in vivo testing, due to some joint structural similarities. In the current study we compared the characteristics of synovial fluid-derived mesenchymal stem cells (SF-MSCs) harvested from horses with different joints degenerative diseases, to those observed in injured human joints. The results of this study showed that SF-MSCs from injured horse joints have substantial chondrogenic potential and they show great similarities to those observed in humans.
\end{abstract}

\section{Rezumat}

Terapia cu celule stem mezenchimale (MSCs) se folosește tot mai frecvent în tratamentul bolilor degenerative. Există mai multe surse de MSCs specifice fiecărui țesut și care au aplicații terapeutice diferite, așadar este nevoie de studii suplimentare pentru a înțelege caracteristicile și diferențele dintre MSCs provenite din surse diferite, potențialul și limitările acestora. Osteoartrita este cea mai frecventă afecțiune articulară întâlnită atât în cazul cailor cât și al oamenilor, iar tratamentele folosite în prezent au limitări. Utilizarea MSCs pentru tratamentul bolilor degenerative osteo-articulare au oferit rezultate încurajatoare, dar studii suplimentare sunt necesare pentru a stabili cel mai sigur şi eficient protocol din punctul de vedere al sursei, al tipului de celule - alogenice sau heterogenice şi doza. Caii pot fi utilizaţi ca model de studiu in vivo, datorită unor caracteristici structurale similare. În studiul de faţă am investigat caracteristicile MSCs din lichidul sinovial (SF-MSCs) provenit de la cai cu afecțiuni articulare degenerative, în comparație cu studiile pe pacienți. Rezultatele acestui studiu demonstrează faptul că SF-MSCs provenite de la nivelul articulațiilor unor cai cu diferite patologii degenerative, au un puternic potential condrogenic și prezintă similarități cu cele provenite de la oameni.

Keywords: equine, human, mesenchymal stem cells, synovial fluid

\section{Introduction}

Articular cartilage is a highly specialized connective tissue, which has no blood, nerves and lymphatic supplies [26]. In case of articular injury and degenerative diseases, this tissue has limited endogenous regenerative capacity due to its low metabolism and avascular structure [7]. In human medicine, the traditional treatment options include administration of drugs to relieve pain, but unwanted side effects occur and pharmaceuticals are not able to maintain or regenerate the injured cartilage $[1,8,15,28]$ and surgery 
including microfracture, debridement, abrasion etc., or total joint replacement, but patients do not completely regain the normal joint function and are at risk of infection $[15,26]$.

Regenerative therapy and mesenchymal stem cells (MSCs) have recently drawn attention in the scientific community for MSCs capacity to repair cartilage [14]. However, to further investigate this new treatment option before introduction in pilot studies on humans, pre-clinical and clinical studies on animals are needed to better characterize synovial fluid-derived mesenchymal stem cells (SF-MSCs) and to understand their mechanism of action.

Horses can be a large animal model for assessment of in vivo efficiency and safety of the human MSCs therapies, due to the interspecific similarities, such as thickness of stifle joint cartilage [6] and tendon structure [27]. Moreover, equine MSCs therapy has become widely used to treat degenerative musculoskeletal disorders in horses, even though there is not enough scientific proof for its efficacy in vivo [26]. Equine MSCs were initially isolated from bone marrow, followed by adipose tissue, umbilical cord, peripheral blood, yolk sac, synovial fluid and synovial membrane [24]. As arthrocentesis is a routine procedure for diagnosis and treatment of joint pathologies, synovial fluid was routinely harvested, and it has been shown that equine SF-MSCs may have regenerative in vivo effects [19]. After intra-articular transplantation, they adhere to the damaged tissues and either differentiate themselves into tissue-specific cells or induce progenitor cells to differentiate [16].

In vitro, SF-MSCs can differentiate into osteogenic, adipogenic, chondrogenic, and tenogenic lineages [19]. The main criteria for their identification are adherence to the plastic of culture flasks, their fibroblast-like morphology and the expression of CD44, CD73, CD90, CD105, and CD166 phenotypic markers [10]. CD44, CD73, CD105, and CD166 are markers of MSCs [11].

Equine SF-MSCs express both major histocompatibility complex (MHC) type I and II and can induce a moderate to severe immune response after intraarticular transplantation. After autologous and allogenic intra-articular transplantation, SF-MSCs could trigger an inflammatory response. Pigott et al. showed that autologous SF-MSCs do not trigger an immune response upon re-injection in the same joint [23]. Pezzanite et al. showed that allogenic transplantation triggers a higher immune response than autologous transplantation [22]. Immune responses that could generate inflammation are a big concern following SF-MSCs transplantation as they could lead to cartilage damage [31]. To reduce at minimum the immunological responses and consequent rejection of autologous or allogeneic grafts, different therapeutic strategies must be investigated. Autologous MSCs transplantation could be an effective therapeutic option, but in vitro studies are needed to assess the differentiation potential of MSCs harvested from the same patient, especially if the source is an injured tissue.

This study aimed to evaluate whether SF-MSC harvested from injured joints of horses have similar in vitro characteristics and chondrogenic potential as those harvested from healthy horses.

\section{Materials and Methods}

The study was conducted in accordance with the European law and regulations for animal Welfare. The protocol was approved by the Committee on the Ethics of the University of Agricultural Sciences and Veterinary Medicine Cluj-Napoca, Romania.

\section{Biological material}

Synovial fluid was collected aseptically from 5 joints of horses with different articular diseases: 2 horses with traumatic arthritis of the metacarpophalangeal joints, 3 horses with osteochondral chip fragments ( 1 in the patellofemoral joint and 2 in the tibiotarsal joint). The arthrocentesis was performed using a $22 \mathrm{G}$ needle. An amount of 5 to $15 \mathrm{~mL}$ of synovial fluid was collected. All samples were collected before any treatment was started.

\section{Isolation and characterization of the SF-MSCS}

To isolate the cells, the samples were centrifuged for 7 minutes at $150 \mathrm{G}$ and $4^{\circ} \mathrm{C}$. The cell deposit was resuspended in a complete medium (DMEM/F12 (Gibco), 10\% foetal serum (Sigma-Aldrich), 1\% Antibiotic-antimycotic (Sigma-Aldrich) and set to incubation. Passage of the cells was done when a confluence of $50-70 \%$ was reached, by treating the cellular cultures with trypsin/EDTA, and after 6 consecutive passages, the cells were immunophenotyped. The characteristics of the stem cells, isolated from the synovial fluid, were assessed through evaluation of the morphology, phenotype and functionality.

To evaluate SF-MSCs clonal capacity, $1 \times 10^{6}$ cells were transferred in a T-25 dish (NuncTM) and incubated at $37^{\circ} \mathrm{C}, 5 \% \mathrm{CO}_{2}$ and $60-90 \%$ humidity. The propagation medium was changed every $2-3$ days. After 10 days, the culture was fixated with ethylic alcohol and stained with an alcoholic solution of $3 \%$ crystal violet for 10 minutes. The percentage of CFU was assessed. To evaluate SF-MSCs migrating potential, a concentration of $2.5 \times 10^{2}$ cells were aggregated in suspended drops in the standard propagation medium. After 48 hours, the newly formed aggregates have been collected and placed in Petri dishes pre-treated with $0.1 \%$ gelatine (Sigma-Aldrich). After 24 hours, the migration potential has been evaluated through measurement of the migration area. The following formula was used: migration capacity $=$ migration area - aggregate size.

To evaluate expression of CD44, CD73 and CD90 cellular markers, immunophenotyping was performed 
at the $6^{\text {th }}$ passage, on samples collected from a horse with coffin joint disease and visible signs of lameness, and from a healthy horse.

The cells were marked with the human monoclonal anti-CD44, anti-CD73 and anti-CD90 antibodies. The flow cytometer FACS CANTO II (BD Biosciences) was used for sample evaluation. The machine was automatically calibrated, using BD Cytometer Setuo \& Tracking Beads (BD Biosciences) and the application $\mathrm{CS} \& \mathrm{~T}$ included in the FACS Diva software. Compensation was done for the PerCPfluorocroms (Peridinin chlorophyll), FITC (fluorescein isothiocyanate) and PE (phycoerythrin). Data were processed using FACS Diva (BD Biosciences) software and results were generated as histograms.

To assess the chondrogenic differentiation capacity, $5 \times 10^{4}$ cells $/ \mathrm{mL}$ were aggregated in Eppendorf tubes. The cellular suspension was centrifuged at $1200 \mathrm{rpm}$ for 7 minutes. On the top of the cellular deposit, an induction medium, containing DMEM/F12 $\left(\right.$ Gibco $\left.^{\circledR}\right)$ supplemented with 1\% ITS (Insulin-Transferin-Seleit,
Sigma $\left.^{\circledR}\right), 50 \mathrm{nM} / \mathrm{L}$ ascorbic acid 2-fosfate $\left(\right.$ Sigma $\left.^{\circledR}\right)$, $100 \mathrm{nM}$ dexamethasone, $10 \mathrm{ng} / \mathrm{mL}$ TGF-b (Transforming Growth Factor, Sigma ${ }^{\circledR}$ ), and 1\% antibiotic/antimycotic $\left(\right.$ Gibco $\left.^{\circledR}\right)$, was added. The adherent cells were treated with proteolytic enzymes (trypsin) 30 days after chondrogenic induction start. After centrifugation, the cellular deposit was resuspended and $180 \mu \mathrm{L}$ of suspension was treated with type I anticollagen antibodies (Anti-COL). Samples were assessed by flow cytometry (Canto II, BD Biosciences).

\section{Results and Discussion}

At 24 hours after incubation, some cells showed the tendency to adhere to plastic, whereas most of them were still in suspension. The attached cells showed increased heterogeneity, most of them being fusiform and round cells (Figure 1). Mostly, on microscopic evaluation, we noticed small cellular groups with the tendency to increase.
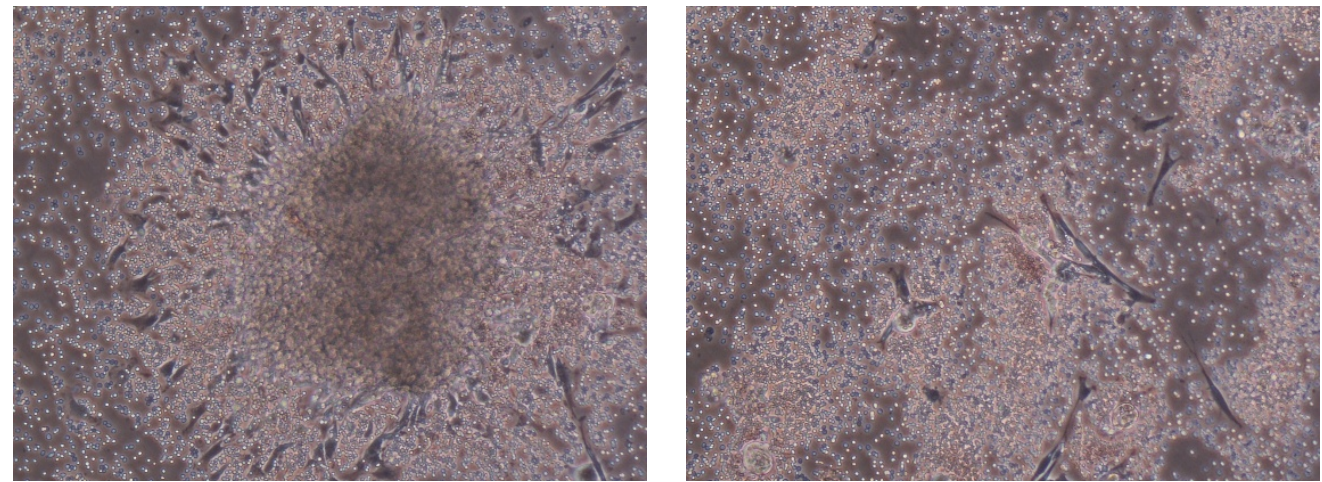

Figure 1.

Morphological aspects of synovial fluid mesenchymal stem cells isolated from horses with joint disease at 24 hours: fusiform and rounded cells are adhered to the plastic of culture flask, but most cells are in suspension (10x)

The first passage was done in the $10^{\text {th }}$ day, when signs of confluence of the culture were noticed. In the first subculture, cells had a rather homogenous aspect with a fibroblastiform aspect. After a couple of days, the cells of the subculture started organizing into clusters, similarly to those observed in the primary culture, but the number of clusters was higher. High proliferation rates were observed in high density clusters, until complete confluence.

Subculture cells had similar behaviour to those in the primary culture. Multiple passages have led to cellular homogeneity and an increase in the number of fibroblastiform cells by the $4^{\text {th }}$ and $5^{\text {th }}$ passage. At 72 hours, cells were moderately heterogenous and organized in small fusiform cell groups containing 5 to 20 cells per group (Figure 2).
The overall results of all six samples show similar aspects with regard to cellular morphology. However, we observed a slight transition towards polygonal cells, contrary to the results of previous studies $[3,4$, $25,30]$. When comparing the morphology of cells harvested from the healthy animal to those harvested from sick ones, we observed a moderate heterogeneity of the first sample.

To assess the clonogenic capacity, the Colony Forming Unit-Fibroblasts (CFU-F) test was performed. The cells were tested after the $5^{\text {th }}$ passage, when the cultures exhibited a high degree of homogeneity, the predominance of fusiform cells and an accentuated bipolarity (Figure 3). 


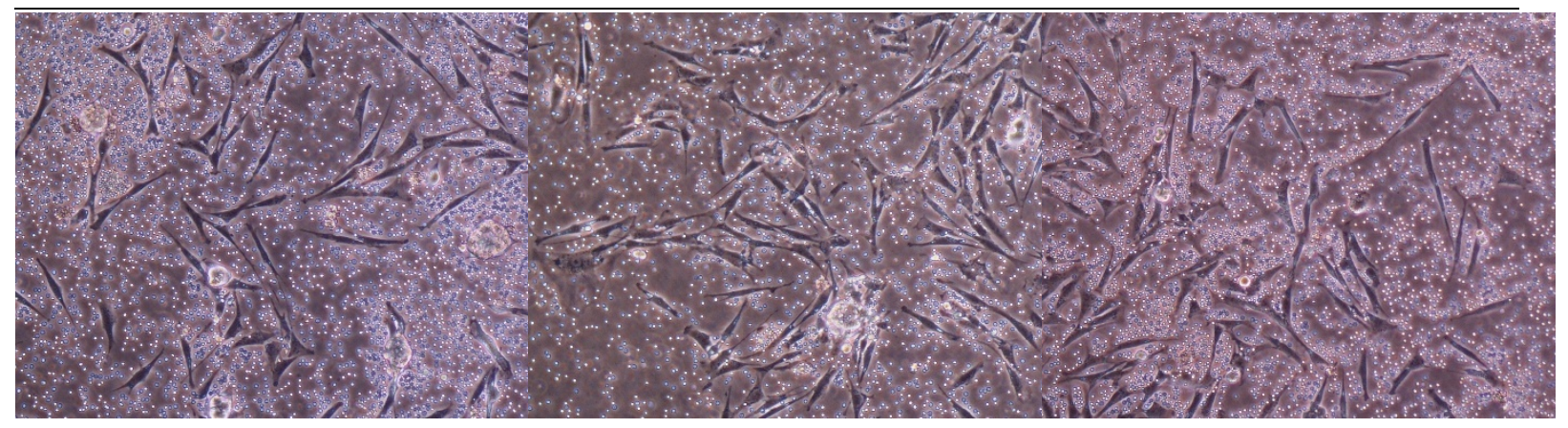

Figure 2.

Morphological aspects of synovial fluid mesenchymal stem cells isolated from horses with joint disease at 72 hours: the cells adhered to the plastic of culture flask are fibroblastiform and their number increases (10x)
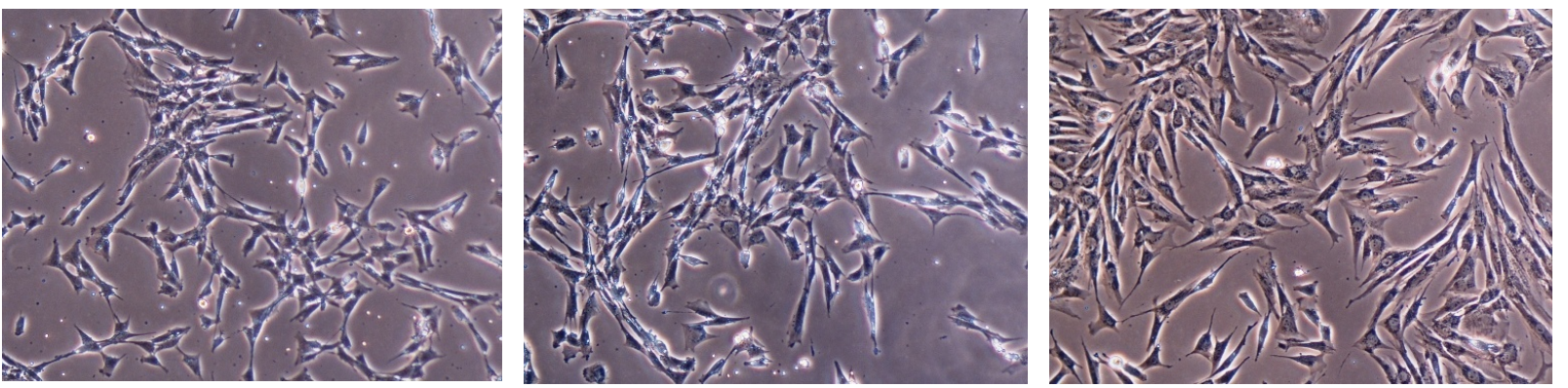

Figure 3.

Morphological aspects of synovial fluid mesenchymal stem cells isolated from horses with joint disease: cell clusters are observed at passage 5 of primary culture (10x)

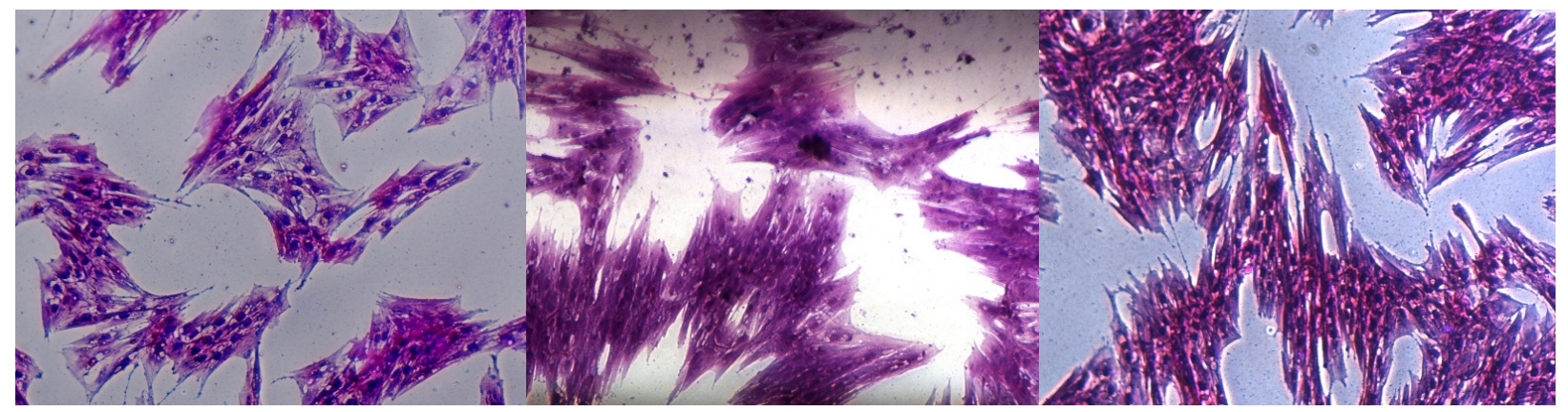

Figure 4.

Morphological aspects of synovial fluid mesenchymal stem cells isolated from horses with joint disease: purple crystal stain of the cell clusters $(10 \mathrm{x})$

In order to determine CFU-F, cultures were fixed 10 days after cultivation, stained with purple crystal and evaluated microscopically (Figure 4). The presence of fibroblast morphology cell colonies was observed. The nucleus occupied a large part of the cell diameter, being mainly central.

We obtained a mean CFU-F of $61.83 \pm 2.42$ colonies/ $100 \mathrm{~cm}^{2}$ from the 6 analysed samples. The sample harvested from the healthy horse had $32 \mathrm{CFU}-\mathrm{F} /$ $100 \mathrm{~cm}^{2}$, this value being significantly lower than the values observed in the samples collected from horses with joint diseases (Figure 5).

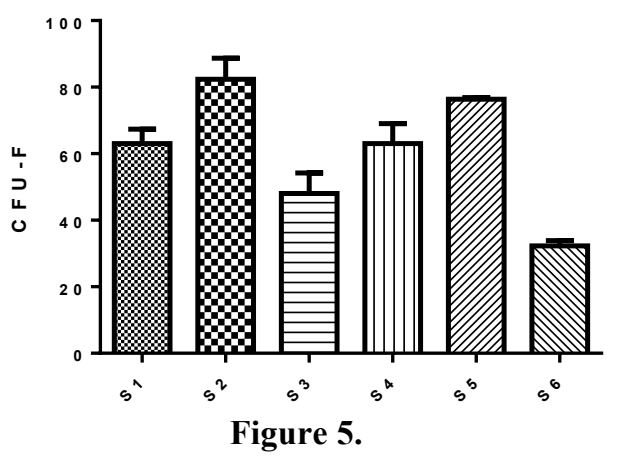

Number of Colony Forming Unit-Fibroblasts (CFU-F) derived from synovial fluid mesenchymal stem cells isolated from horses with joint disease (S1, S2, S3,

S4 and S5) and from the healthy horse (S6) 
FARMACIA, 2019, Vol. 67, 3

The increase in the number of SF-MSCs in the synovial fluid of horses with joint injuries is due to their tropism for injured sites. Cell migration depends on multiple factors, such as growth factors or chemokines secreted by injured cells and the activation of the immune system [29].

The evaluation of the differentiation capacity was achieved by directing the differentiation of isolated cells towards the chondrogenic lineage. For this, two isolates, one from the healthy horse and one from the horse with fracture of the extensorius process in the distal interphalangeal joint of the left anterior limb were used. The isolated cells were aggregated to form cell pellets. These pellets were kept in suspension for 14 days, before they were added to cultivation plates pre-treated with $1 \%$ gelatine.

After cell attachment and proliferation around cellular aggregates, cells from the healthy horse became fusiform with a well-developed nucleus. After 3 days of attachment, in addition to fusiform cells, large, star-shaped and polygonal cells were observed, some of which were large and flattened. Also, there was a tendency for progressive decrease of the number of cells with rounded morphology. In the horse with joint injuries, polyhedral and stellate cells with a welldeveloped nucleus were observed, their dimensions and morphology being uneven. Overall, there are no significant differences in the cell morphology assessed at the beginning of the chondrogenic differentiation, between the cell cultures from the healthy horse and those from the horse with joint disease. 30 days after induction of chondrogenesis, the predominance of stellate cells and a decrease in those with spindle morphology was observed. In stellate morphology cells, the presence of large, rounded, dispersed chromate nuclei, with a variable number of cellular extensions, is found (Figure 6).

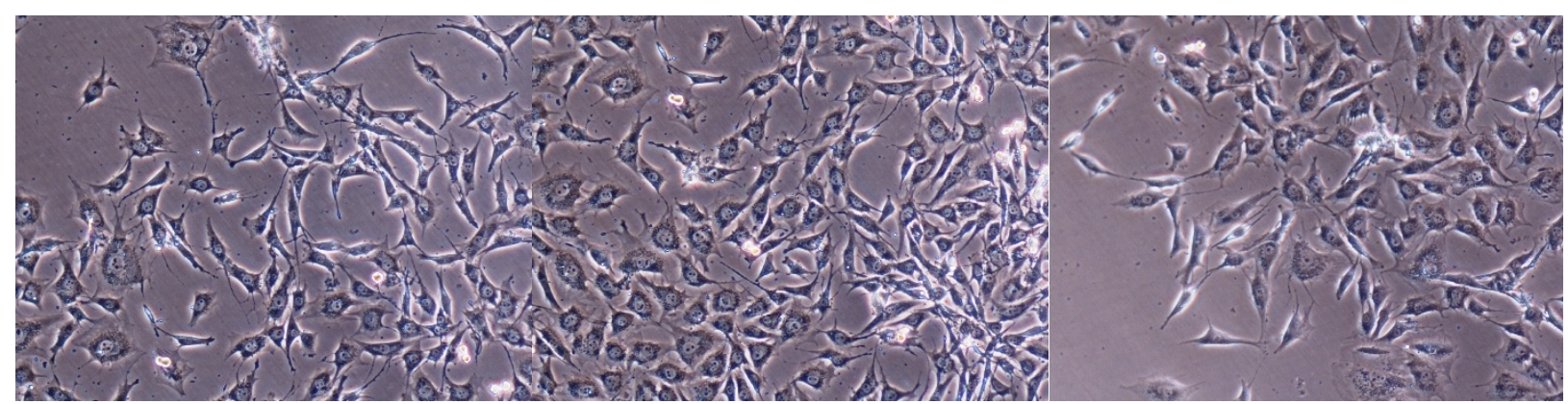

Figure 6.

Morphological characteristics of synovial fluid mesenchymal stem cells isolated from healthy horse at 30 days post chondrogenic induction

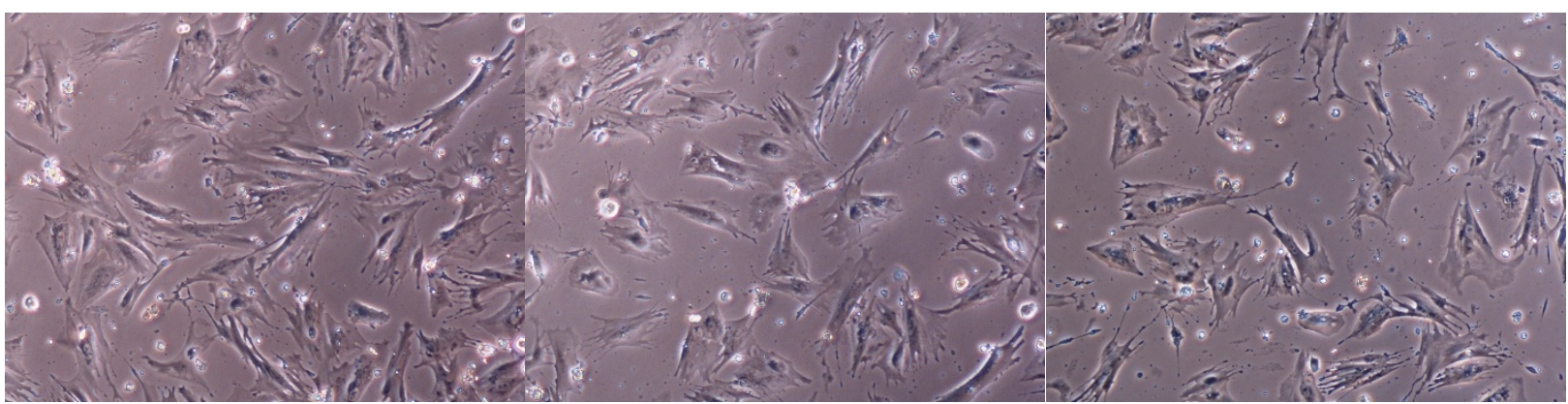

Figure 7.

Morphological characteristics of synovial fluid mesenchymal stem cells isolated from horses with joint disease at 30 days post chondrogenic induction

The cells derived from injured joints had a heterogeneous aspect and a decreased density. The presence of stellate, polyhedral, fusiform and round cells with heterogenous dimension (Figure 7) was observed. This might be due to the inhibitory effect of inflammation on the chondrogenic differentiation capacity of the cells.
We evaluated the differentiation capacity using a FACS Canto II flow cytometer (BD Biosciences). The immunophenotypic analysis was performed in order to evaluate the expression of the CD44, CD73 and CD90 markers. CD44 was present on $99.9 \%$ of the cells, both from the healthy horse and from the horse with fracture of the extensorius process (Figure 8). 


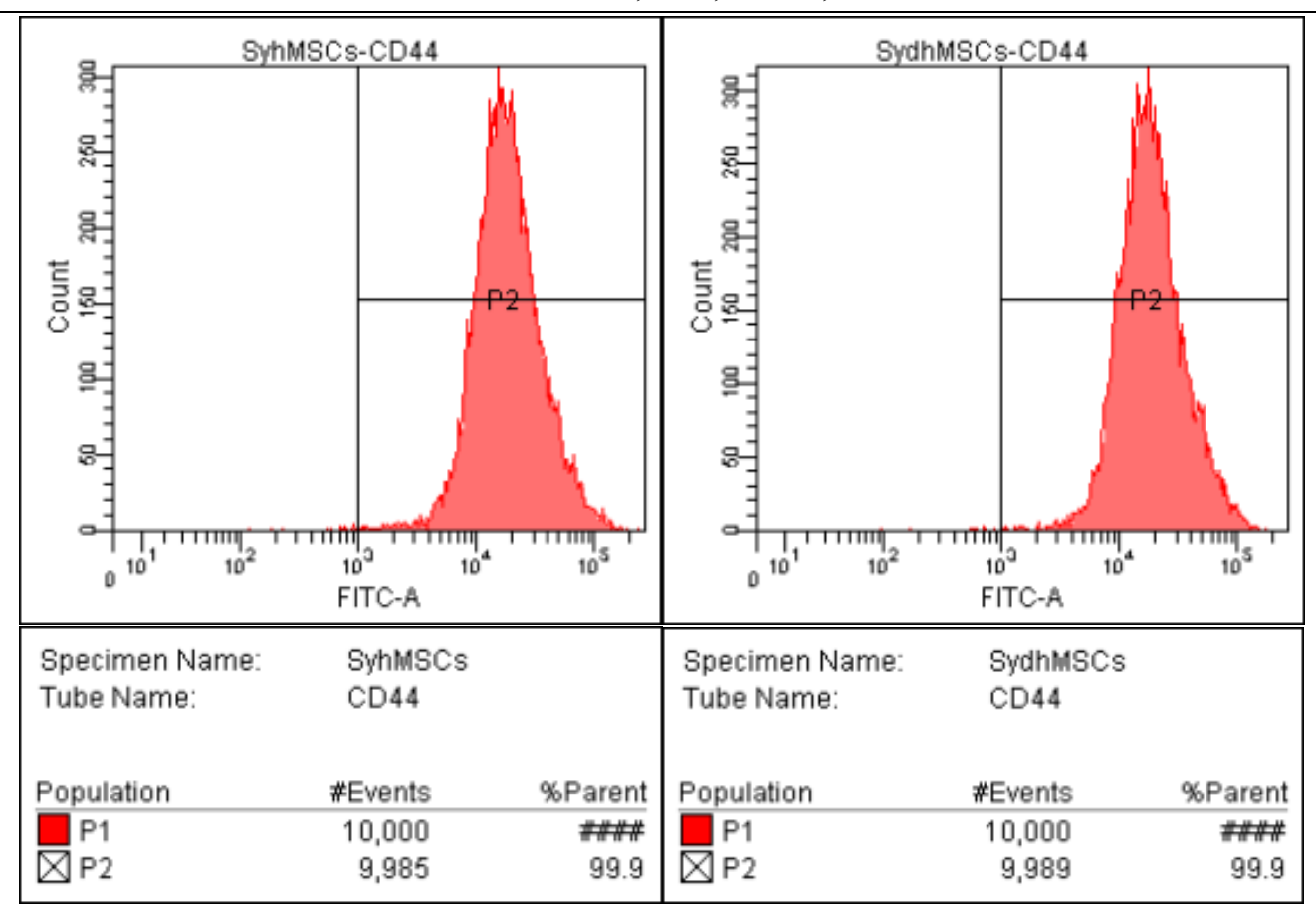

Figure 8.

Results of the immunophenotypic assay regarding the CD44 surface marker

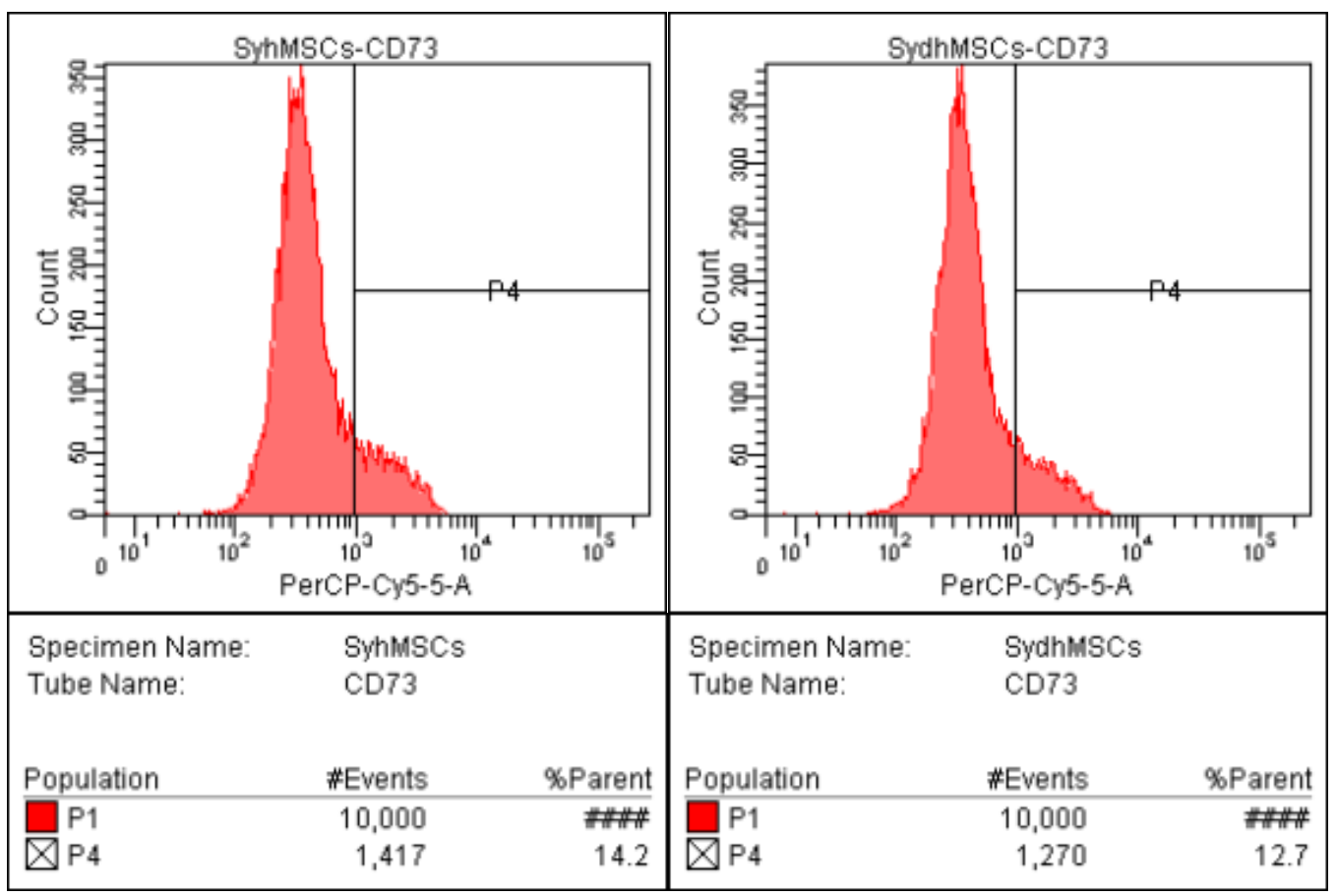

Figure 9.

Results of the immunophenotypic assay regarding the CD73 surface marker

Only $14.2 \%$ of the cells from the healthy horse and $12.7 \%$ from the horse with joint injury expressed positivity for the CD73 surface marker (Figure 9). None of the SF-MSCs expressed the CD73 surface marker for both samples. Although the minimal criteria required for the definition of human MSCs state that they have to express positivity for the CD73 surface protein, other studies performed on stem cells harvested from equines have shown the same negative result $[12,21]$.

All of the cells from the healthy animal expressed the CD90 surface marker and $93.4 \%$ of the cells from injured animals (Figure 10). These results are similar to those obtained by the International Cytotherapy Society [5]. 


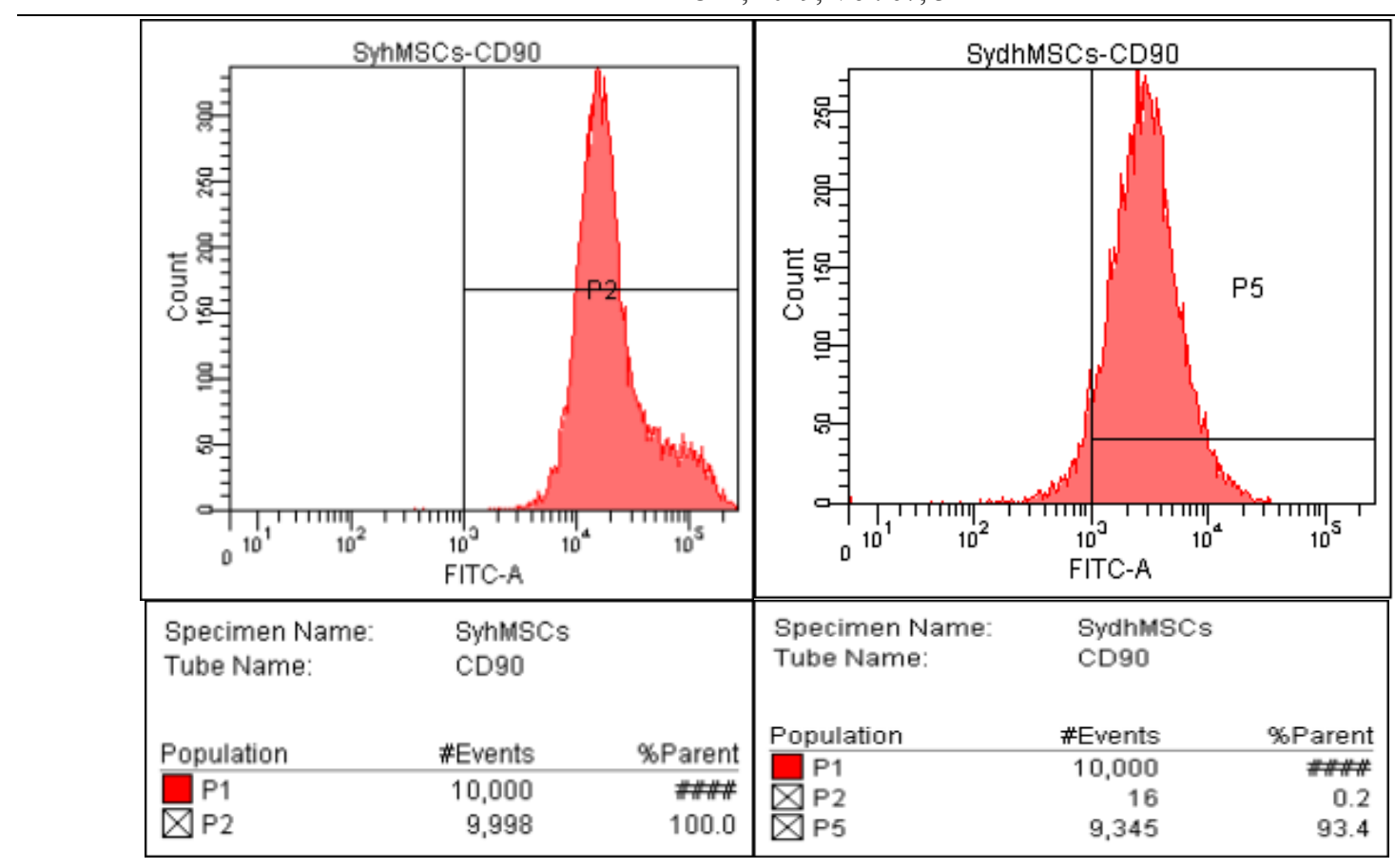

Figure 10.

Results of the immunophenotypic assay regarding the CD90 surface marker

At the evaluation of the differentiation capacity of synovial fluid mesenchymal stem cells, we identified a $95.1 \%$ positive collagen cell count in the healthy animal and $12.6 \%$ in the injured one (Figure 11). There is a significant difference between the two values, the chondrogenic differentiation capacity being about 8 times higher in the case of the healthy animal. A study evaluating the ability to differentiate mesenchymal stem cells from the bone marrow in patients with osteoarthritis claims that their potential to support a chondrogenic differentiation is significantly reduced relative to healthy patients [20]. Thus, it can be argued that lesioning of the joint tissues affects the ability of cellular differentiation towards chondrocites.

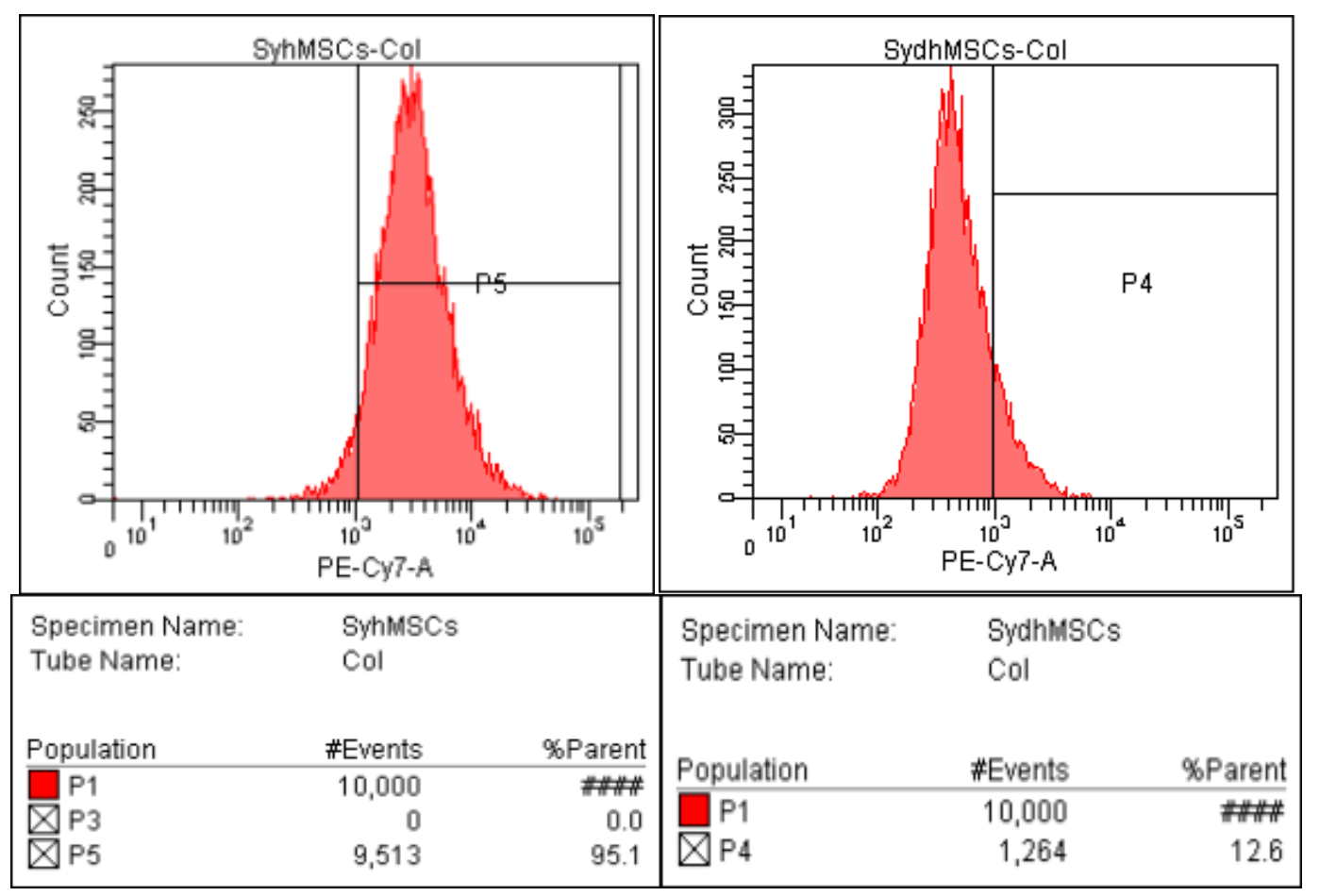

Figure 11.

Results of the immunophenotypic assay regarding the collagen cell count 
MSCs represent a heterogeneous cell population characterized by multipotency, proliferation and adhesion to the cultivation substrate, and a fibroblastlike morphology [9]. Also, MSCs have to demonstrate the ability to differentiate into at least 3 cellular types: osteoblasts, condroblasts and adipocytes [5]. Studies of Murata and collaborators (2014), performed on MSCs isolated from synovial fluid in horses, confirmed their positivity for surface markers CD44 and $\mathrm{CD} 90$, the ability to differentiate into condrogenic, osteogenic, adipogenic and tenogenic, but also the presence of fibroblastic morphology. Moreover, the number of CFU has been shown to be significantly higher in horses with osteochondral defects than in healthy animals, these results being similar to those obtained in this study. The same increased number of stem cells was encountered in human joints with different articular disease and stem cells from synovial fluid seemed to offer best results in treating the affected joints [19]. These similarities prove that the horse can be a suitable species for the study of synovial fluid mesenchymal stem cells in vitro.

In the current study, the evaluation of clonogenic capacity of mesenchymal stem cells identified a significantly lower number of CFU-F in the healthy animal in comparison to the injured ones. Thus, our results are similar to those of previous studies in which the clonogenic potential of SF-MSCs from healthy horses was compared with that of horses diagnosed with osteoarthritis, rheumatoid arthritis, meniscus or cross-ligament lesions [13, 17, 18, 25]. The potential of MSCs to migrate from the vascular bed to the tissue level, most likely to respond to the signals that occur after the initiation of the injury is well established. Although the exact recruitment mechanism is not fully understood, cytokines, their receptors and adhesion molecules seem to play an important role [2]. Thus, we can assume that the synovial fluid is a stem cell reservoir that is able to migrate to the site of the injury to participate in the inflammatory response.

The capacity of chondrogenic differentiation was assessed following targeted differentiation and treatment of cells with type I anti-collagen antibodies. The chondrogenic differentiation capacity was approximately 8 times lower in the horse with fracture of extensorious process than in the healthy horse. Murphy et al. suggests that the decrease in progenitor cell differentiation capacity in patients with osteoarthritis may play a major role in the degradation of articular cartilage. However, there is limited evidence of stem cell differentiation capacity in response to cellular damage due to joint injury.

It has been hypothesized that MSCs participate in homeostasis, remodelling and tissue repair by ensuring the replacement of mature lost cells as a result of physiological wear, senescence or joint lesion [25]. The contribution of synovial stem cells to the spontaneous repair of cartilage [27] and the importance of synovial fluid in providing a cell-friendly environment provide the premises for studying the role of MSCs from synovial fluid in the articular homeostasis. Further studies regarding the regenerative effects of MSCs are necessary since spontaneous healing of injured joints has been encountered [17] and the horse seems to be a good model.

\section{Conclusions}

The results of clinical studies in horses that assess the possible use of SF-MSCs, due to their self-renewing potential and multipotentiality, might represent a valuable tool for gaining new insights into the treatment of human joint diseases. In this current study, SF-MSCs from horses with different degenerative joint diseases showed the same characteristics to human SF-MSCs, which make the horse a good model for further research both in vivo and in vitro.

\section{References}

1. Bijlsma JW, Berenbaum F, Lafeber FP, Osteoarthritis: an update with relevance for clinical practice. Lancet, 2011; 377(9783): 2115-2126.

2. Chamberlain G, Fox J, Ashton B, Middleton J, Concise review: mesenchymal stem cells: their phenotype, differentiation capacity, immunological features, and potential for homing. Stem Cells, 2007; 25(11): 2739-2749.

3. Colter DC, Class R, DiGirolamo CM, Prockop DJ, Rapid expansion of recycling stem cells in cultures of plastic-adherent cells from human bone marrow. Proceed Nat Acad Sci., 2000; 97(7): 3213-3218.

4. Colter DC, Sekiya I, Prockop DJ, Identification of a subpopulation of rapidly self-renewing and multipotential adult stem cells in colonies of human marrow stromal cells. Proceed Nat Acad Sci., 2001; 98(14): 7841-7845.

5. Dominici MLBK, Le Blanc K, Mueller I, SlaperCortenbach I, Marini FC, Krause DS, Deans RJ, Keating A, Prockop DJ, Horwitz E, Minimal criteria for defining multipotent mesenchymal stromal cells. The International Society for Cellular Therapy position statement. Cytotherapy, 2006; 8(4): 315-317.

6. Frisbie DD, Cross MW, McIlwraith CW, A comparative study of articular cartilage thickness in the stifle of animal species used in human pre-clinical studies compared to articular cartilage thickness in the human knee. Vet Comp Orthop Traumatol., 2006; 19: 142-146.

7. Fritz J, Janssen P, Gaissmaier C, Schewe B, Weise K, Articular cartilage defects in the knee-basics, therapies and results. Injury, 2008; 39(Suppl 1): 50-57.

8. Guo N, Li B, Jiang X, The efficacy of a phytoestrogen-rich Chinese medicine on senile osteoporosis. Farmacia, 2018; 66(6): 1076-1080.

9. Horwitz EM, Le Blanc K, Dominici M, Mueller I, Slaper-Cortenbach I, Cetal MF, Deans RJ, Krause DS, Keating A, Clarification of the nomenclature for MSC: The International Society for Cellular Therapy position statement. Cytotherapy, 2005; 7(5): 393-395. 
10. Arufe MC, De la Fuente A, Fuentes I, De Toro, FJ, Chondrogenic potential of subpopulations of cells expressing mesenchymal stem cell markers derived from human synovial membranes. J Cell Biochem., 2010; 111(4): 834-845.

11. Fernandes TL, Kimura HA, Pinheiro CCG, Shimomura K, Nakamura N, Ferreira JRM, Gomoll AH, Bueno DF, Human synovial MSC good manufacturing practices for articular cartilage regeneration. Tiss Engineer Part C Meth., 2019; 24(12): 709-716.

12. Iacono E, Brunori L, Pirrone A, Pagliaro PP, Ricci $\mathrm{F}$, Merlo $\mathrm{B}$, Isolation, Isolation, characterization and differentiation of mesenchymal stem cells from amniotic fluid, umbilical cord blood and Wharton's jelly in the horse. Reproduction, 2012; 143(4): 455468.

13. Jones EA, Crawford A, English A, Henshaw K, Mundy J, Corscadden D, Chapman T, Emery P, Hatton P, McGonagle D. Synovial fluid mesenchymal stem cells in health and early osteoarthritis: Detection and functional evaluation at the single cell level. Arthrit \& Rheum., 2008; 58(6): 1731-1740.

14. Jorgenson KD, Hart DA, Krawetz R, Sen A, Production of adult human synovial fluid-derived mesenchymal stem cells in stirred-suspension culture. Stem Cells Int., 2018; 2018: 1-16.

15. Khan WS, Johnson DS, Hardingham TE, The potential of stem cells in the treatment of knee cartilage defects. The Knee, 2010; 17(6): 369-374.

16. Koch TG, Berg LC, Betts Dean H, Current and future regenerative medicine - Principles, concepts, and therapeutic use of stem cell therapy and tissue engineering in equine medicine. Can Vet J., 2009; 50(2): 155-165.

17. Matsukura Y, Muneta T, Tsuji K, Koga H, Sekiya I, Mesenchymal stem cells in synovial fluid increase after meniscus injury. Clin Orthop Relat Res., 2014; 472(5): 1357-1364.

18. Morito T, Muneta T, Hara K, Ju YJ, Mochizuki T, Umezawa A, Sekiya I, Synovial fluid-derived mesenchymal stem cells increase after intra-articular ligament injury in humans. Rheumatology, 2008; 47(8): 1137-1143.

19. Murata D, Miyakoshi D, Hatazoe T, Miura N, Fujiki M, Nakayama K, Misumi K, Multipotency of equine mesenchymal stem cells derived from synovial fluid. Vet J., 2014; 202(1): 53-61.

20. Murphy J. Mary, Dixon K, Beck S, Fabian D, Barry $F$, Reduced chondrogenic and adipogenic activity of mesenchymal stem cells from patients with advanced osteoarthritis. Arthrit \& Rheumat., 2002; 46(3): 704713.

21. Pascucci L, Curina G, Mercati F, Marini C, Dall'Aglio C, Paternesi B, Ceccarelli P, Flow cytometric characterization of culture expanded multipotent mesenchymal stromal cells (MSCs) from horse adipose tissue: towards the definition of minimal stemness criteria. Vet Immun Immunopath., 2011; 144(3): 499-506.

22. Pezzanite LM, Fortier LA, Antczak DF, Cassano JM, Brosnahan MM, Miller D, Schnabel LV, Equine allogeneic bone marrow-derived mesenchymal stromal cells elicit antibody responses in vivo. Stem Cell Res Ther., 2015; 6(1): 1-11.

23. Pigott JH, Ishihara A, Wellman ML, Russell DS, Bertone $\mathrm{AL}$, Investigation of the immune response to autologous, allogeneic, and xenogeneic mesenchymal stem cells after intra-articular injection in horses. Vet Immunol Immunopath., 2013; 156(1-2): 99-106.

24. Prado AA, Favaron PO, da Silva LC, Baccarin RY, Maria DA, Characterization of mesenchymal stem cells derived from the equine synovial fluid and membrane. BMC Vet Res., 2015; 11: 1-13.

25. Sekiya I, Ojima M, Suzuki S, Yamaga M, Horie M, Koga H, Tsuji K, Ogishima S, Tanaka H, Muneta T, Human mesenchymal stem cells in synovial fluid increase in the knee with degenerated cartilage and osteoarthritis. J Orthop Res., 2012; 30(6): 943-949.

26. Simon TM, Jackson DW, Articular cartilage: injury pathways and treatment options. Sports Med Arthroscopy Rev., 2018; 26(1): 31-39.

27. Smith RK, Webbon PM, Harnessing the stem cell for the treatment of tendon injuries: heralding a new dawn?. Brit J Sport Med., 2005; 39: 582-584.

28. Trăistaru R, Alexandru DO, Kamal D, Kamal KC, Rogoveanu $\mathrm{O}$, The role of herbal extracts in knee osteoarthritis females rehabilitation. Farmacia, 2018; 66(3): 507-513.

29. Spaeth E, Klopp A, Dembinski J, Andreeff M, Marini $\mathrm{F}$, Inflammation and tumor microenvironments: defining the migratory itinerary of mesenchymal stem cells. Gene Ther., 2008, 15(10): 730-738.

30. Yoshimura H, Muneta T, Nimura A, Yokoyama A, Koga H, Sekiya I, Comparison of rat mesenchymal stem cells derived from bone marrow, synovium, periosteum, adipose tissue, and muscle. Cell Tissue Res., 2007; 327(3): 449-462.

31. Zayed M, Adair S, Ursini T, Schumacher J, Misk $\mathrm{N}$, Dhar M, Concepts and challenges in the use of mesenchymal stem cells as a treatment for cartilage damage in the horse. Res Vet Sci., 2018; 118: 317-323. 